\title{
Review of White by Bret Easton Ellis
}

Although he has published six novels and a collection of stories previously, Bret Easton Ellis's reputation rests largely on a pair of novels whose popular culture-infused plots bookended the 1980s: his debut, Less Than Zero, an unflinching look into the nihilistic excess of the MTV generation; and American Psycho, a Wall Street satire which initially provoked outrage and disgust via one of literature's most infamously unreliable narrators, Patrick Bateman, but later enjoyed success as a Hollywood film and Broadway musical. Readers have grown to expect from Ellis darkly comic social satire mixed with increasingly stylized prose and the author as a cultural gadfly. His most recent novel (Imperial Bedrooms) was published in 2010 and since then, Ellis's focus seems to have shifted to posting provocative comments on Twitter and hosting his eponymous podcast. It is within the context of his four decades as a public figure that Ellis's first nonfiction book White appears.

Turning the old saw that "you can't judge a book by its cover" on its head, the first thing one notices with this book is the minimalist cover, which is glaringly white apart from the title, Ellis's name, and a series of reflective watermarked terms which could simultaneously describe Ellis himself and suggest some connection to the word white: writer, critic, lover, hater, tweeter, free-speaker, transgressive, privileged, and male. In aggregate, these terms could function as a word cloud illustrating perhaps how Ellis sees himself; or how Ellis is perceived by others; or to leverage a term Ellis deploys regularly in the book, they could simply be "poses" meant to garner attention or "likes." The collection is organized into eight loosely conceived essays_-"Empire," "Acting," "Second self," "Post-sex," "Liking," "Tweeting," "Post-empire," and "These Days"which are primarily concerned with three interlocking issues: mapping the conditions in which Generation X went from childhood on to adulthood (and the attendant worldview from said upbringing); examining the farreaching effects of social media across artistic, political, and generational 
lines (often through the lens of how current events unfold on Twitter); and tracing Ellis's life as a writer through all this, with particular attention given to the period around which he wrote American Psycho.

Ellis opens the book with an epigraph from Janet Malcolm's The Journalist and the Murderer - itself a provocative and controversial text ${ }^{1}$ and the epigraph concludes: "Hypocrisy is the grease that keeps society functioning in an agreeable way" (Malcolm 55). Ellis uses the epigraph to both signal to the reader one of his prevailing considerations throughout the book White--"that empowerment doesn't come from liking this or another, but from being true to our messy contradictory selves" (120) and perhaps to inoculate himself from the inevitable criticism his "messy, contradictory" book might provoke for being exactly what he suggests it will be. Those readers familiar with Ellis's Twitter feed or podcast will recognize the contrarian stance he frequently takes: Ellis the gay man quarreling with GLAAD and disliking the critically-acclaimed film Moonlight; Ellis the writer arguing for an artist's prerogative to take creative risks or inhabit characters far different from their own personal biographies while vigorously opposing the actor Matt Bomer, a gay man, taking on the role of Christian Grey in the 50 Shades of Grey series; or Ellis the self-described bastion of inclusivity celebrating his friendships across political stripes and cultural backgrounds-he shared cocaine with Jean Michel Basquiat after all! — while at the same time repeatedly claiming that the establishment media and people, in general, take Donald Trump and his purposely divisive and incendiary remarks and attacks against immigrants, Muslims, the queer community, or the press far too seriously.

As Ellis tells it, Generation Xers are more resilient, self-sufficient, and better prepared for the complexities of life than younger generations, as he writes that “[w]e didn't get ribbons for doing a good job and we weren't awarded for just showing up: there were actual winners and losers" (17). These life lessons are cast in stark contrast to the Millennials, whom Ellis derides throughout the book as "Generation Wuss." Part of the blame he places on his fellow Gen Xers who rejected the laissez-faire approach of their parents, and instead were coddling and, in a sense, failing their children by

not teaching them how to deal with life's hardships about how things actually work: people might not like you, this person will not love you

1 Malcolm's book examines the murky ethical relationship between journalist Joe McGuinniss and convicted murderer Jeffrey MacDonald. MacDonald later sued McGuinniss for libel and Malcolm's book uses the McGuinniss-MacDonald dynamic as a kind of case study in how journalists interact with their subjects. 
back, kids are really cruel, work sucks, it's hard to be good at something, your days will be made up of failure and disappointment, you're not talented, people suffer, people grow old, people die. (131)

Instead of processing experiences and growing into adulthood, Ellis sees Millennials as retreating to safe spaces and "victim narratives," easily offended, and quick to silence dissenting opinions on social media or demand various forms of social justice via Twitter. On the one hand, he frames these differences along free speech lines-that the younger generation has betrayed certain ideals of liberalism-but on the other hand, his objections could be easily attributed along generational dividing lines: those whose lives have been immersed in technology, the internet, and social media since birth, and those who have not.

Throughout the book, Ellis offers a wide array of opinions on a myriad of issues (e.g., why country music is better than Kendrick Lamar; why internet pornography has ruined sex; or why wealthy white Californians forfeit the right to be outraged by the Trump administration's treatment of refugees). In a discussion comparing the aesthetic merits of the films Fruitvale Station and Weekend in his essay "Post-sex," Ellis responds to criticism that perhaps his whiteness may contribute to him preferring Weekend as a film and limit his ability to identify with the black protagonist of Fruituale Station being shot and killed at the end of the film to the same degree as black viewers:

I'd argue that living without a direct experience of poverty or statesponsored violence, growing up without ever being presumed a guaranteed threat in public spaces and never facing an existence where protection is hard to come by don't equate to a lack of empathy, judgment, or understanding on my part and don't rightly and automatically demand my silence. (91)

Put simply, Ellis claims that a lack of direct experience of a given issue-in this case, being a victim of systemic racism-is not equivalent to lacking empathy or understanding of the issue. Given Ellis's position, it comes as something of a surprise when, in parts of two different essays in the book, he chastises Meryl Streep for her speech at the Golden Globes where she criticized Donald Trump for mocking a disabled reporter and celebrated the diversity of the nominees of the various awards. In his essay "Liking" he devotes several paragraphs to Streep's failure to use the speech to eulogize various people she worked with (Michael Cimino, Mike Nichols, Nora Ephron, Carrie Fisher); in "These Days," he "takes Meryl Streep to task for her outraged anti-Trump speech ... the same week she'd put her Greenwich Village townhouse on the market for thirty million 
dollars" (248). In both cases, his argument undermines what he claims are core beliefs of his: free speech and an ability to empathize with others. In terms of free speech, Streep should be able to use her platform to express whatever she wishes; in terms of empathizing with others, the monetary value of a potential property sale has nothing to do with concern for the disabled and stands as a salient example of a non sequitur.

There are various segments in the book where Ellis reflects on his writing process with Less Than Zero or American Psycho. Some claims are easy enough to take at face value, such as when he explains how the character of Julian in Less Than Zero was named after Richard Gere's Julian in American Gigolo. Moreover, in fairness, Ellis did position Donald Trump as a kind of surrogate father figure for the character of Patrick Bateman in American Psycho, a decision he claims was deliberate after reading The Art of the Deal and researching various dubious dealings of Trump. However, from the demonstrable facts, Ellis looks back at various events in the 2016 election and afterward with all the self-certainty of hindsight. (There is no evidence that people in 1987 presumed Donald Trump to be a future president, for instance, and Trump's 2016 win might appear retrospectively inevitable thanks more to recency bias than literary prophecy, but Ellis depicts those events as if he knew the outcome all along.) For a writer who claims to care so little about politics, he devotes a significant portion of the book to the presidential election, Trump's remarks, his social circle's response to Trump, and social-media-based outrage. If each essay were taken on its own, perhaps Ellis's claims would be reasonably coherent, but when read alongside each other with so many disparate and conflicting ideas from essay to essay, the connections become either muddled or actively undermined.

This is not to suggest that the essays lack insight entirely. Although Ellis's criticism of social media is often impressionistic and broad stroke, he raises a vital point when he considers the consequences for artists in the current social climate and the tendency towards silencing those with opposing views, or de-platforming speakers at American university campuses:

How could artists flower in an environment while terrified about expressing themselves however they wanted to, or take big creative risks that often walked along the edges of good taste or even blasphemy, or simply allowed them to step into someone else's shoes without being accused of cultural appropriation? (261)

Similarly, he astutely observes that the establishment media responded poorly or ineffectively with near-constant outrage when confronted 
with a legitimately disruptive force such as Donald Trump. Given the divergent elements and competing polemical aims of Ellis's White, it might be concluded that his project in the book is to make the world safe for hypocrisy. Consequently, his contrarian tendencies lead him into the trap of false equivalence: while it might be a useful exercise to consider that Twitter is not a space one should take too seriously, not all Twitter accounts are the same, a fact that Ellis never considers. (For instance, one particular Twitter account is backed by one of the most formidable militaries the world has ever known, replete with a nuclear arsenal. Celebrities such as Taylor Swift or Kanye West may have massive followings online, but their tweets do not have the same potential to destabilize alliances or regions, separate families, or send the stock market plummeting 600 points in a single day.) In his zeal for ironic distance, Ellis would rather take his readers through the reasons why the most important character in Ferris Bueller's Day Off was Charlie Sheen in his brief cameo at the end of the film than to think through how empathy or free speech could be encouraged or supported amidst social-media-exacerbated hostilities. Although the essays aim at some degree of the moral complexity and nuance present in his fiction, they never quite deliver either the intellectual clarity or emotional intensity of his fictional narratives.

\section{Works CiTED}

Ellis, Bret Easton. White. London: Picador, 2019. Print.

Malcolm, Janet. The Journalist and the Murderer. New York: Random, 2011. Print.

Mark Tardi is the author of three books and numerous other publications. His most recent book, The Circus of Trust, was published by Dalkey Archive Press in August 2017. A former Fulbright scholar, he earned his MFA from Brown University and is on faculty at the University of Łódź in the Department of American Literature and Culture.

mark.tardi@uni.lodz.pl 